\title{
Factors Affecting the Discipline of Red Island Tourists on the Implementation of the New Normal Era Covid-19 Health Protocol in Banyuwangi
}

Gufron Wahyudi

Faculty of Public Health, University of Bakti Indonesia

Email:

gufron.wahyu@yahoo.co.id
Received : October $4^{\text {nd }} 2021$

Accepted : October $15^{\text {rd }} 2021$

Published : November $27^{\text {th }} 2021$

\begin{abstract}
The World Health Organization (WHO) has officially designated the Corona Virus or (Covid-19) as a pandemic. Covid-19 is similar to Middle East Respiratory Syndrome (MERS-CoV) and (SARS-CoV) The death rate from Covid-19 on September 5, 2020 on a global scale, the data shows as many as 26,310,505 confirmed Covid-19 with a total of 868,810 died and around $17,525,973$ people were declared cured. In Indonesia, the number of patients who were confirmed positive for Covid-19 was 190,665, of which 7,940 were declared dead while 136.401 were declared cured. In East Java Province, there were 34,278 positive Covid-19 cases. In a smaller scope, the Banyuwangi district shows the number of confirmed Covid-19 patients as many as 851 (Banyuwangi Covid-19 Information and Monitoring Site, 2020). This type of research is quantitative with a research design that is an analytical survey. The sample technique used is Quota Sampling, the number of samples used is 140 tourists. The measuring tools used are questionnaires and observation sheets. Analysis of the data used is Multiple Regression. The results of the study are presented in tabular and descriptive form. Based on the results of research and data analysis, it can be concluded. Based on the results of the $t$ test, it was found that the level of knowledge, attitudes, and roles of officers had a partial influence on the implementation of health protocols. Based on the results of the $\mathrm{f}$ test, it was found that variable $X$ had a simultaneous influence on variable Y. The results of the statistical test of the study could be concluded with the results of the SPSS version 16 test, that the factors analyzed by the researcher were the level of knowledge, attitudes, hand washing facilities and the role of officers had an influence on discipline. tourists in implementing health protocols.
\end{abstract}

Keywords: Covid-19, new normal, health protocol

Copyright (C) 2021 IIK STRADA Indonesia All right reserved.

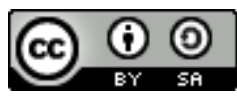

This is an open-acces article distributed under the terms of the Creative Commons AttributionShareAlike 4.0 International License. 


\section{INTRODUCTION}

The World Health Organization (WHO) has officially designated the Corona Virus or (Covid19) as a pandemic. Covid-19 is similar to Middle East Respiratory Syndrome (MERS$\mathrm{CoV})$ and (SARS-CoV) The death rate due to Covid-19 on September 5, 2020, on a global scale, the data shows as many as 26,310,505 confirmed Covid-19 with a total of 868,810 deaths and around $17,525,973$ people are declared cured. In Indonesia, the number of patients who were confirmed positive for Covid-19 was 190,665, of which 7,940 were declared dead while 136.401 were declared cured. In East Java Province, there were 34,278 positive Covid-19 cases. In a smaller scope, the Banyuwangi district shows the number of confirmed Covid-19 patients as many as 851 (Banyuwangi Covid-19 Information and Monitoring Site, 2020). During the Covid-19 pandemic until the implementation of the new normal era in 2020, there was a drastic decrease in foreign tourist arrivals of up to 60 percent, while for domestic tourist visits, judging by the number of hotel units that had been ordered, it was still stable up to 90 percent (Merdeka, 2020) Risk of movement of people and community gatherings in public places and facilities, have a fairly large potential for Covid-19 transmission (Ministry of Health, 2020). New Normal while on vacation at tourist attractions emphasizes the concepts of cleanliness, health, and safety (Cleanliness, Health, and Safety or called CHS). The CHS concept is a strategy designed by the Ministry of Tourism and Creative Economy (Kemenparekraf) so that tourism sector workers can remain productive and safe in the midst of a pandemic (Pinemo, 2020)

\section{MATERIALS AND METHODS}

This type of research is quantitative research with an analytical survey research design. The study was conducted in August 2020. The independent variable of this study was the discipline factor of red island tourists and the dependent variable was the application of health protocols. The total population in the study included 216 tourists who visited Pulau Merah in August 2020. The sampling technique used Quota Sampling on 140 predetermined samples. Data were collected using questionnaires and observation sheets. Analysis of the data used using Multiple Regression. The research results are presented in tabular and descriptive form.

\section{RESULTS}

a. Characteristics of respondents based on knowledge level

Table 4.4 Frequency Distribution by Level of Knowledge of Tourists on Red Island in 2020

\begin{tabular}{ccc}
\hline Knowledge level & Frequency & Percent \\
\hline Well & 48 & 34.3 \\
\hline Enough & 62 & 44.3 \\
\hline Not enough & 30 & 21.4 \\
\hline Total & $\mathbf{1 4 0}$ & $\mathbf{1 0 0}$
\end{tabular}

Based on table 4.4 above, it can be seen that the frequency of the highest level of knowledge is at the sufficient level, namely as many as 62 people (44.3\%), followed by the good knowledge level as many as 48 people (34.3\%) and the level of less knowledge as many as 30 people (21.4\%).

b. Characteristics of respondents based on where to wash hands

Table 4.6. Frequency Distribution Based on Handwashing Places in Red Island in 2020

\begin{tabular}{ccc}
\hline Hand washing facilities & Frequency & Percent \\
\hline Well & 40 & 28.6 \\
\hline Enough & 75 & 53.6 \\
\hline Not enough & 25 & 17.8 \\
\hline Total & $\mathbf{1 4 0}$ & $\mathbf{1 0 0}$ \\
\hline
\end{tabular}


Based on table 4.6 above, it can be seen that the frequency of the most hand washing places is on a sufficient scale, namely as many as 75 people (53.6\%), followed by a good scale of 40 people $(28.6 \%)$ and on a less scale as many as 25 people $(17.8 \%)$.

c. Characteristics of respondents based on attitude

Table 4.5 Distribution of Frequency Based on Tourist Attitudes on Red Island in 2020

\begin{tabular}{ccc}
\hline Attitude & Frequency & Percent \\
\hline Well & 81 & 57.9 \\
\hline Enough & 49 & 35.0 \\
\hline Not enough & 10 & 7.1 \\
\hline Total & $\mathbf{1 4 0}$ & $\mathbf{1 0 0}$
\end{tabular}

Based on table 4.5 above, it can be seen that the highest frequency of attitudes is on a good scale, namely as many as 81 people $(57.9 \%)$, followed by tourist attitudes on a sufficient scale as many as 49 people (35\%) and tourist attitudes on a less scale as many as 10 people (7.1 $\%)$.

d. Characteristics of respondents based on the role of officers

Table 4.7 Frequency Distribution by Role of Officers on Red Island in 2020

\begin{tabular}{ccc}
\hline Attitude & Frequency & Percent \\
\hline Well & 45 & 32.1 \\
\hline Enough & 80 & 57.1 \\
\hline Not enough & 15 & 10.8 \\
\hline Total & $\mathbf{1 4 0}$ & $\mathbf{1 0 0}$ \\
\hline
\end{tabular}

Based on table 4.7 above, it can be seen that the frequency of the role of hand officers at most is on the sufficient scale, namely as many as 80 people $(57.1 \%)$, followed by the good scale as many as 45 people $(32.1 \%)$ and the less scale as many as 15 people $(10.8 \%)$.

e. Characteristics of respondents based on the application of health protocols

Table 4.8 Distribution of Frequency Based on Implementation of Health Protocols in Red Island in 2020

\begin{tabular}{ccc}
\hline Implementation of Health Protocol & Frequency & Percent \\
\hline Well & 107 & 76.4 \\
\hline Enough & 28 & 20 \\
\hline Not enough & 5 & 3.6 \\
\hline Total & $\mathbf{1 4 0}$ & $\mathbf{1 0 0}$ \\
\hline
\end{tabular}

Based on table 4.8 above, it can be seen that the frequency of application of health protocols, the majority of tourists apply health protocols well, as shown by the level of answer Yes based on the researcher's observations as many as 123 people (87.9\%), and 17 people who do not apply health protocols well ( $12.1 \%)$.

f. Cross tabulation 
Table 4.9 Cross-tabulation between Knowledge Levels and Implementation of Health Protocols in Red Island in 2020

\begin{tabular}{|c|c|c|c|c|c|c|c|c|c|}
\hline \multirow{3}{*}{ No } & \multirow{3}{*}{ Knowledge level } & \multicolumn{8}{|c|}{ Health Protocol } \\
\hline & & \multicolumn{2}{|c|}{ Well } & \multicolumn{2}{|c|}{ Enough } & \multicolumn{2}{|c|}{ Not enough } & \multicolumn{2}{|c|}{ Total } \\
\hline & & $\mathbf{N}$ & $\%$ & $\mathbf{N}$ & $\%$ & $\mathbf{N}$ & $\%$ & $\mathbf{N}$ & $\%$ \\
\hline 1 & Well & 48 & 34.3 & 0 & 0 & 0 & 0 & 48 & 34.3 \\
\hline 2 & Enough & 59 & 42.1 & 3 & 2.1 & 0 & 0 & 62 & 44.3 \\
\hline 3 & Not enough & 0 & 0 & 25 & 17.9 & 5 & 3.6 & 30 & 21.4 \\
\hline & Amount & 107 & 76.4 & 28 & 20 & 5 & 3.6 & 140 & 100 \\
\hline
\end{tabular}

Based on table 4.9 above, it shows that the level of knowledge of tourists on a good and sufficient scale occupies the most places, namely a good scale of 48 people (34.3\%) and a sufficient scale of 59 people (42.1\%). there are less than 5 people $(9.3 \%)$ who apply.

Table 4.10 Cross Tabulation Between Attitudes and Implementation of Health Protocols in Red Island in 2020

\begin{tabular}{cccccccccc}
\hline \multirow{2}{*}{ No } & \multirow{8}{*}{ Attitude } & \multicolumn{9}{c}{ Enough } & Not enough & \multicolumn{2}{c}{ Total } \\
\cline { 3 - 11 } & & $\mathbf{N}$ & $\mathbf{\%}$ & $\mathbf{N}$ & $\mathbf{\%}$ & $\mathbf{N}$ & $\mathbf{\%}$ & $\mathbf{N}$ & $\mathbf{\%}$ \\
\hline & Well & 81 & 57.9 & 0 & 0 & 0 & 0 & 81 & 57.9 \\
\hline 1 & Enough & 26 & 18.6 & 23 & 16.4 & 0 & 0 & 49 & 35 \\
\hline 2 & Not enough & 0 & 0 & 5 & 3.6 & 5 & 3.6 & 10 & 7.1 \\
\hline 3 & Amount & 107 & 76.4 & 28 & 20 & 5 & 3.6 & 140 & 100 \\
\hline & & & & & & & & &
\end{tabular}

Based on table 4.10 above, it shows that the majority of tourists with a good attitude as many as 81 people $(57.9 \%)$ apply health protocols well. Likewise, tourists with a sufficient attitude as many as 26 people (16.6\%) applied health protocols well and those who did not apply as many as 5 people $(3.6 \%)$.

Table 4.11 Cross Tabulation Between Handwashing Places and Implementation of Tourist Health Protocols on Red Island in 2020

\begin{tabular}{cccccccccc}
\hline \multirow{2}{*}{ No Hand washing facilities } & \multicolumn{9}{c}{ Health Protocol } \\
\cline { 3 - 11 } & & \multicolumn{4}{c}{ Well } & \multicolumn{1}{c}{ Enough } & \multicolumn{1}{c}{ Not enough } & \multicolumn{2}{c}{ Total } \\
\cline { 2 - 11 } & Well & 40 & 28.6 & 0 & 0 & 0 & 0 & 40 & 28.6 \\
\hline 1 & Enough & 67 & 47.9 & 8 & 5.7 & 0 & 0 & 75 & 53.6 \\
\hline 2 & Not enough & 0 & 0 & 20 & 14.3 & 5 & 3.6 & 25 & 17.9 \\
\hline 3 & Amount & 107 & 76.4 & 28 & 20 & 5 & 3.6 & 140 & 100 \\
\hline & & & & & & & & &
\end{tabular}

Based on table 4.11, it shows that adequate hand washing facilities are in good category and quite influential on the implementation of health protocols, and vice versa, inadequate hand washing facilities or on a scale that has less effect on the implementation of health protocols are shown in table 4.11 above. 
Table 4.12 Cross Tabulation Between the Role of Officers and the Implementation of the Health Protocol for Tourists on Red Island in 2020

\begin{tabular}{cccccccccc}
\hline \multirow{2}{*}{ No } & \multirow{8}{*}{ Officer Role } & \multicolumn{1}{c}{ Health Protocol } \\
\cline { 3 - 11 } & & $\mathbf{N}$ & $\mathbf{\%}$ & $\mathbf{N}$ & $\mathbf{\%}$ & $\mathbf{N}$ & $\mathbf{\%}$ & $\mathbf{N}$ & $\mathbf{\%}$ \\
\cline { 3 - 11 } & Well & 45 & 32.1 & 0 & 0 & 0 & 0 & 45 & 32.1 \\
\hline 1 & Enough & 62 & 44.3 & 18 & 12.9 & 0 & 0 & 80 & 57.1 \\
\hline 2 & Not enough & 0 & 0 & 10 & 7.1 & 5 & 3.6 & 15 & 10.7 \\
\hline 3 & Amount & 107 & 76.4 & 28 & 20 & 5 & 3.6 & 140 & 100 \\
\hline & Amoll
\end{tabular}

Based on table 4.12 above, it can be seen that the role of officers on the red island is in the range of quite to good scale, this is proven by the data presented in the table above .

\section{DISCUSSION}

a. Correlation between knowledge level and implementation of health protocol

Based on table 4.9 above, it shows that the level of knowledge of tourists on a good and sufficient scale occupies the most places, namely a good scale of 48 people (34.3\%) and a sufficient scale of 59 people (42.1\%). there are less than 5 people $(9.3 \%)$ who apply.

These results are in line with research conducted by Riyadi \& Putri Larasaty at the Directorate of Statistical Analysis and Development, showing that the variable of the highest level of education completed has a significant effect on the level of community compliance in the application of health protocols with a positive relationship direction. In other words, someone with a higher level of education will have a tendency to always be obedient and obedient to the application of health protocols considering their knowledge regarding the dangers of Covid-19 and information regarding controlling the spread of Covid-19.

From the results of the research above and the existing theory, it can be concluded that a person's level of knowledge is very influential on how they should behave, this is also reflected in the application of health protocols, with good knowledge, they will realize how important it is to implement health protocols during a pandemic.

b. The correlation between the attitude of tourists and the application of health protocols

Based on table 4.10 above, it shows that the majority of tourists with a good attitude as many as 81 people $(57.9 \%)$ apply health protocols well. Likewise, tourists with a sufficient attitude as many as 26 people (16.6\%) applied health protocols well and those who did not apply as many as 5 people $(3.6 \%)$.

This result is in line with research conducted by Riyadi \& Putri Larasaty at the Directorate of Statistical Analysis and Development. Concerning the variable level of concern and a person's attitude in responding to the news of Covid-19 has a significant influence on the level of community compliance in the application of health protocols with a positive relationship direction. In other words, people who have high concerns and good attitudes about the news of Covid-19 have a tendency to always obey and adhere to the implementation of health protocols.

From the results of the research above and the existing theory, it can be concluded that a person's attitude is very influential on how he should behave, this is also reflected in the application of health protocols, the better a person's attitude, the more they can respect and care for each other's environment by implementing health protocols.

c. Correlation between hand washing facilities and implementation of health protocols

Based on table 4.11, it shows that adequate hand washing facilities are in good category and quite influential on the implementation of health protocols, and vice versa, inadequate hand washing facilities or on a scale that has less effect on the implementation of health protocols are shown in table 4.11 above. 
In line with the research conducted by Hayatun Nufus and Teuku Tahlil in The Availability Of Facilities and Handwashing Behavior Among Elementary School Students, it was stated that based on the research results, hand washing facilities were incomplete/inadequate, most of the respondents (63\%) stated that hand washing behavior was not good. Maria, Maryanti and Hery in explaining good facilities, the availability of complete facilities such as hand towels, sink containers, which are adequate in each class will help improve student behavior in improving attitudes in carrying out hand washing before eating.

From the existing theory and the research above, it can be concluded that the availability of adequate hand washing facilities also influences the application of health protocols in tourist attractions.

d. Correlation between the role of officers and the implementation of health protocols

Based on table 4.12, it can be seen that the role of officers on the red island ranges from moderate to good, this is evidenced by the data presented in table 4.12 where the majority of respondents stated that officers participated in implementing health protocols.

From the results of the research above, and supported by existing theories, it can be concluded that tourist site officers play a role in reminding, urging and directing and supervising tourists in terms of implementing health protocols.

From the review of the research results above and based on the correlation between variables, it was found that the discipline factors of tourists that affect the application of health protocols, namely the level of tourist knowledge, tourist attitudes, hand washing places and the role of tourist site officers have a significant correlation, this is also proven by the results data analysis statistics with multiple regression techniques using $\mathrm{t}$ test and $\mathrm{f}$ test as described below;

- $\quad$ T Uji test

Coefficients $^{\text {a }}$

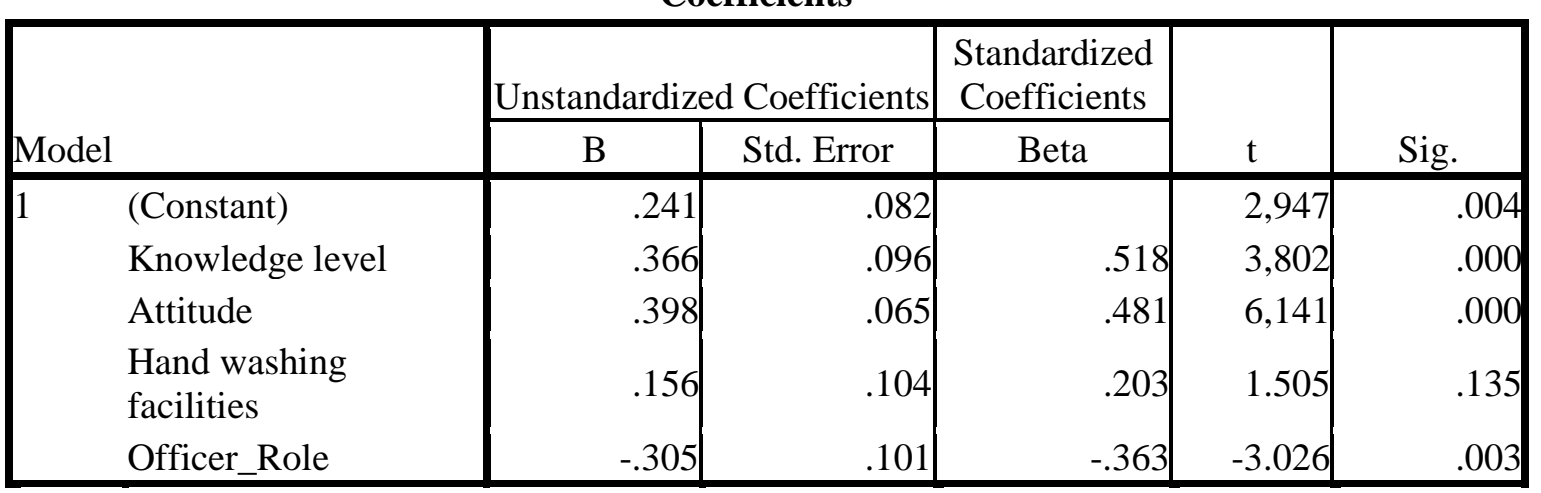

a. Dependent Variable:Implementation_Protocol_Health

Based on the results of the $t$ test can be analyzed;

1) The level of knowledge with sig $0.000<0.05$ and t count $3.802>$ t table 1.977 , so it can be concluded that there is an influence between the level of knowledge of tourists and the application of health protocols.

2) Attitude with sig $0.000<0.05$ and t count $6.141>\mathrm{t}$ table 1.977 , so it can be concluded that there is an influence between tourist attitudes and the application of health protocols.

3) Hand washing place with sig $0.135>0.05$ and t count $1.505<\mathrm{t}$ table 1.977 , so it can be concluded that there is no effect between hand washing place and the application of health protocols.

4) The role of officers with sig $0.03<0.05$ and $t$ count $3.026>t$ table 1.977 , so it can be concluded that there is an influence between the role of tourist attractions officers and the application of health protocols. 
- $\quad$ F Uji test

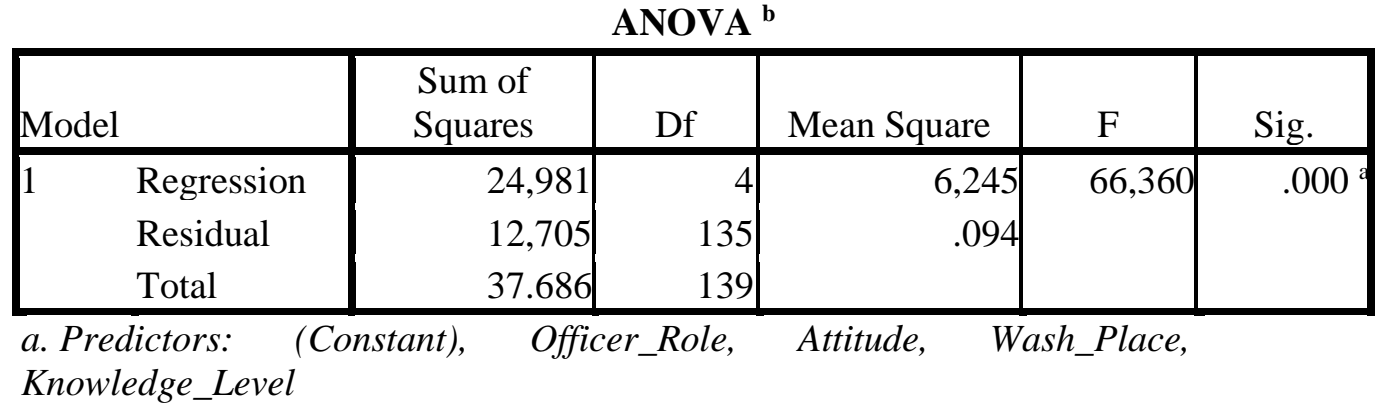

b. Dependent Variable: Deployment_Protocol_Health

Based on the results of the $f$ test can be analyzed;

1) $\mathrm{f}$ : sig $0.000<0.05$ and $\mathrm{f}$ count $66.360>\mathrm{f}$ table 2.44 , so it can be concluded that there is an influence between the $\mathrm{x}$ variable on the $\mathrm{y}$ variable.

\section{CONCLUSION}

Based on the results of research and data analysis that identifies and analyzes the factors that influence the Discipline of Red Island Tourists towards the Implementation of the New Normal Era Covid-19 Health Protocol in Banyuwangi Regency, it can be concluded as follows:

1. Based on the results of the $t$ test, it was found that the variables of the level of knowledge, attitude, and the role of officers had a partial influence on the implementation of health protocols

2. Based on the results of the $\mathrm{f}$ test, it is found that the variable $\mathrm{X}$ has a simultaneous influence on the variable $\mathrm{Y}$

3. The results of the statistical test of the study can be concluded with the results of the SPSS version 16 test, that the factors analyzed by the researcher, namely the level of knowledge, attitudes, hand washing facilities and the role of officers have an influence on tourist discipline in implementing health protocols.

\section{REFERENCES}

Anindya Fajria. 19 Mei 2020. Apa Itu New Normal. https://www.wartaekonomi.co.id/read286203/apa-itu-new-normal diakses pada 20 Agustus 2020

Arikunto, S. (2013). Prosedur Penelitian : Suatu Pendekatan Praktik. Jakarta : Rineka Cipta.

Bara, Deismon. (2018). Peran Disiplin Masyarakat Dalam Menjaga Budaya Hidup Bersih Terhadap Lingkungan. Jurnal Holistik. Vol.11(21): 1-2.

Dinas Pariwisata dan Kebudayaan Banyuwangi tahun 2019, di akses di https://www.banyuwangikab.go.id/profil/pariwisata.html

Dohlia, Patraet (2018). Pengaruh Disiplin Kerja dan Motivasi Kerja PNS pada Kantor Camat di Kabupaten Solok Selatan. Jurnal Administrasi dan Kebijakan Publik. Vol.3(3): 261-273

Dr Tin Herawati. 08 Juni 2020. Peran Keluarga Menjadi Kunci Utama di Era Pandemi COVID-19 dan New Normal. http://sehatnegeriku.kemkes.go.id/baca/rilismedia/20200602/3134014/keluarga-kunci-memasukiera-new-normal/. Diakses pada 01 Oktober 2020.

Dwisaputra, Maihendro (2017). Motivasi Pengunjung Ke Kota Wisata Bukittinggi Sumatera Barat. Jurnal Jom Fisip. Vol.4(2): 1-14

Eticon. 26 Mei 2020. Protokol Kesehatan di Destinasi Wisata saat Memasuki New Normal. https://eticon.co.id/protokol-kesehatan-destinasi-wisata/. Diakses pada tanggal 01 Oktober 2020.

Firmansyah, Tresna(2017). Analisis Kepercayaan Tokoh Pada Novel Tambora Karya Agus Sumbogo Tinjauan Teori Antropologi Sastra. Skripsi. Universitas Muhammadiyah Malang

Gayatri, Dewi (2015). Mendesain Instrumen Pengukuran Sikap. Jurnal Keperawatan Indonesia. Vol. 8(2): 76-80.

Hidayat, A. Aziz Alimul. (2010). Metode Penelitian Kebidanan dan Teknik Analisa Data. Jakarta : Salemba Medika.

Habibi, Andrian (2020). Normal Baru Pasca Covid-19. Jurnal Buletin Hukum \& Keadilan. Vol.4(1): 197-204 
Hamadi, H. B., Syarweni., N. (2020). Pengaruh New Normal Di Masa Mendatang.(https://www.academia.edu/43424536/_Pengaruh_new_normal_di_masa_mendatang _, diakses 10 September 2020).

Iralia,Ristanti (2017). Gambaran Persepsi dan Tingkat Pengetahuan Pengunjung tentang Keberadaan Pos Kesehatan Wisata dan Peran Tenaga Kesehatan di Taman Rekreasi Kota Batu. Skripsi. Universitas Muhammadiyah Malang.

Kementerian Kesehatan Republik Indonesia tahun 2020, di akses di https://www.kemkes.go.id/article/view/20062000001/menkes-terbitkan-protokol-kesehatan-ditempat-umum.html

Kompas. 27 Mei 2020. Fase New Normal kantor dan ruang publik harus sediakan tempat cuci tangan. https://nasional.kompas.com/read/2020/05/27/17361821/fase-new-normal-kantor-danruang-publik-harus-sediakan-tempat-cuci-tangan. Diakses pada tanggal 01 Oktober 2020.

Mardiyah, Fatimah. 7 September 2020. Apakah yang dimaksud Protokol Kesehatan Covid-19. https://tirto.id/apakah-yang-dimaksud-protokol-kesehatan-covid-19-f3W3. Diakses pada 21 Agustus 2020.

Mattufajar, Novedha Getta (2019). Analisis Potensi Pariwisata di Obyek Wisata Kahyangan Di Kecamatan Tirtoyomo Kabupaten Wonogiri Tahun 2018. Publikasi Ilmiah. 1-9

Mundakir, (2006). Komunikasi Keperawatan, Aplikasi dalam Pelayanan, Yogyakarta: Graha Ilmu.

Murahartawy, Bayu Mahendratta (2014). Implementasi Web Portal Pariwisata Indonesia Menggunakan Joomla Berbasis Content Management System (CMS). Jurnal Rekayasa Sistem \& Industri. Vol.1(1): 160-165

Musa, Mustara., Abdul (2019). Korelasi Sikap Disiplin dan Tanggung Jawab Terhadap Indeks Prestasi Akumulatif Mahasiswa Fakultas Ilmu Olahraga Peserta Kegiatan Outdoor Based Character Bulding (OBCB). Jurnal Ilmiah Sport Coaching and Education. Vol.3: 158-166

Melya Findi dan Wera Damianus. 29 Mei 2020. PERAN KELUARGA DALAM MENGHADAPI SITUASI $N E W$

NORMAL. http://sehatnegeriku.kemkes.go.id/baca/rilismedia/20200526/1833966/biasakan-new-normal-jadiperan-penting-keluarga/. Diakses pada tanggal 01 Oktober 2020.

Nashar (2015). Program Dini Penegakan Disiplin Kerja Pegawai. Jurnal Nuansa. Vol.12(1): 19-46

Nursalam.2013. Konsep dan Penerapan Metodelogi Penelitian Ilmu Keperawatan. Jakarta: PT. Salemba Medika.

Notoatmodjo, Soekidjo. (2012). Pendidikan dan Perilaku Kesehatan, Jakarta : PT. Rineka Cipta.

Notoadmodjo, S. (2010). "Metode Penelitian Kesehatan". RinekaCipta. Jakarta.

Noviyanti, A., Nurani, N. (2020). Kemenparekraf Akan Menerapkan Program CHS di Destinasi, Bali Jadi Pilot Project. https://kumparan.com/kumparantravel/kemenparekraf-akan-menerapkanprogram-chs-di-destinasi-bali-jadi-pilot-project-1tQ3sbnXjBI/full.diakses pada 28 September 2020

Peraturan Bupati Banyuwangi Nomor 39 Tahun 2020, Tentang Pedoman Tatanan Kehidupan Baru Pada Kondisi Pandemi Covid-19 Di Kabupaten Banyuwangi

Pandyki, (2013). Hubungan antara Keyakinan Pemimpin dengan Kepuasan Kerja Karyawan. Skripsi. Universitas Gajah Mada.

Rizkon, Akhmad (2019). Pengaruh Metode Islah Mubasyir Terhadap Kedisiplinan Santri Pondok Pesantren. Jurnal Pendidikan Islam Indonesia. Vol.4(1): 23-29

Sugiyono.2016. Metode Penelitian Manajemen. Bandung: Alfabeta.

Sunchila. 14 Juli 2020. Pengertian New Normal Saat Pandemi. https://www.sunchila.com/blog/pengertian-new-normal-saat-pandemi// diakses pada 30 September 2020.

Situs Informasi dan Pantauan Covid-19 Banyuwangi tahun 2020, di akses di https://corona.banyuwangikab.go.id/

Satuan Tugas Penanganan Covid-19 Banyuwangi tahun 2020, di akses di https://covid19.go.id/

Suratman,(2014). Hubungan antara Enabling Factor dan Reinforcing Factor terhadap Minat Berobat Masyarakat di Wilayah Kerja Puskesmas 2 Banjarnegara. Skripsi. Universitas Muhammadiyah $\underline{\text { Purwokerto }}$ 
Suwena, I Ketut ., I Gusti Ngurah Widyatmaja (2017). Pengetahuan Dasar Ilmu Pariwisata. Penerbit Pustaka Larasan: Fakultas Pariwisata Universitas Udaya Denpasar.

Taufik,A., Eka, A. A.(2020). "Dampak Pandemi Covid-19 Terhadap Bisnis Dan Eksistensi Platform Online". Jurnal Pengembangan Wiraswasta. Vol. 22 No.1 April 2020. pp. 21-32.

Wahyudi, D., Hayati, M. (2020). Pengabdian Masyarakat dari Rumah di Era New Normal. Lampung : CV. Creative Tugu Pena.

Yuliantari, Kartika., Suci Nurul Ulfa (2016). Disiplin Kerja Mempengaruhi Kinerja Karyawan Pada PT. Megah Bangun Baja Semesta Jakarta. Jurnal Administrasi Kantor. Vol.4(2): 354-373 